\title{
Loss of bronchoprotection to Salbutamol during sputum induction with hypertonic saline: implications for asthma therapy
}

\author{
Hongyu Wang ${ }^{1,2}$, Melanie Kjarsgaard ${ }^{1,2}$, Terence Ho ${ }^{1,2}$, John D. Brannan ${ }^{3}$ and Parameswaran Nair , $^{1 *}$ (1)
}

\begin{abstract}
Background: Sputum induction with hypertonic saline in obstructive airway diseases is generally safe. However, saline induces bronchoconstriction in some patients despite pre-medication with Salbutamol. Our objectives were to investigate the predictors of failure of Salbutamol to protect against saline-induced-bronchoconstriction in patients with asthma and COPD and to evaluate implications for asthma therapy.

Methods: Retrospective survey on a database of 3565 patients with obstructive airway diseases who had sputum induced with hypertonic saline. The effect of baseline FEV ${ }_{1}$, bronchitis and concomitant medication on salineinduced-bronchoconstriction ( $\geq 15 \%$ drop in $\mathrm{FEV}_{1}$ ) were examined by logistic regression analysis. A subgroup had this re-examined 8-12 weeks after decreasing long-acting-beta-2-agonist dose or after adding Montelukast, which included an assessment of mast cell activity in sputum.
\end{abstract}

Results: 222 (6.2\%) patients had saline-induced-bronchoconstriction despite pre-treatment with inhaled Salbutamol. Baseline airflow obstruction ( $\mathrm{FEV}, \%$ predicted $<60 \%$ OR 3.29, $\mathrm{p}<0.001$ ) and long-acting-beta-agonist use (OR 2.02, $p=0.001$ ), but not bronchitis, were predictors of saline-induced-bronchoconstriction, which decreased when longacting-beta-agonist dose was decreased. Refractoriness to subsequent bronchodilation was associated with mast cell activity and was attenuated by Montelukast.

Conclusion: Sputum induction with saline provides information on bronchitis and additional physiological data on tolerance to beta-agonists and mast cell activity that may have implications for clinical therapy.

Keywords: Hypertonic saline, Sputum induction, Bronchoconstriction, Long-acting beta-agonists, Asthma, COPD

\section{Background}

Hypertonic saline nebulization is a relatively non-invasive procedure to collect sputum for airway diseases even in the presence of moderate to severe airflow obstruction [1]. Occasionally, despite pre-medication with Salbutamol, saline-induced bronchoconstriction (SIB) occurs. This may be related to baseline airflow obstruction, increased airway hyperresponsiveness (AHR), or lowered

\footnotetext{
*Correspondence: parames@mcmaster.ca

${ }^{1}$ Firestone Institute for Respiratory Health, St. Joseph's Healthcare, 50

Charlton Avenue East, Hamilton, ON L8N 4A6, Canada

Full list of author information is available at the end of the article
}

sensitivity to $\beta_{2}$-agonists [2-5]. The loss of bronchoprotection is considered to be primarily due to $\beta_{2}$-receptor downregulation and desensitization [3], and the refractoriness to subsequent bronchodilation with Salbutamol (i.e. recovery time) is considered to be mediated partly by leukotrienes and thus reflecting mast cell activity [6].

The objectives of this retrospective cross-sectional survey were to determine predictors of SIB in a large cohort of patients with airway disease and to illustrate the wealth of information on airway physiology that could be obtained during the process of sputum induction. As proof of principle, we also evaluated the effect

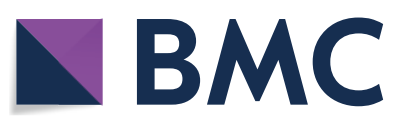

(c) The Author(s) 2018. This article is distributed under the terms of the Creative Commons Attribution 4.0 International License (http://creativecommons.org/licenses/by/4.0/), which permits unrestricted use, distribution, and reproduction in any medium, provided you give appropriate credit to the original author(s) and the source, provide a link to the Creative Commons license, and indicate if changes were made. The Creative Commons Public Domain Dedication waiver (http://creativecommons.org/ publicdomain/zero/1.0/) applies to the data made available in this article, unless otherwise stated. 
of LABA-dose reduction and leukotriene antagonism on SIB in a non-randomised observational study.

\section{Methods}

Data were collected from a computerized database of induced sputum cell counts from January, 2004 to January, 2008 at the Firestone Institute for Respiratory Health in Hamilton, Ontario. The database contained the following information: age, gender, post-bronchodilator spirometry, $\mathrm{FEV}_{1}$ after each concentration increment of saline (3, 4, 5\%, each for $7 \mathrm{~min})$, and after subsequent administration of Salbutamol, sputum cell counts, referring physician diagnosis, indication for the test, and current relevant medications. Three groups of patients were included in the analysis: current asthma with or without associated chronic airflow limitation, possible asthma (when the referring physician was not certain of the diagnosis), and non-asthmatic COPD. A diagnosis of asthma was based on previous evidence of reversible airflow limitation (an increase in $\mathrm{FEV}_{1} \geq 15 \%$ and $\geq 200 \mathrm{ml}$ from the pre-bronchodilator value) or airway hyper responsiveness (a provocative concentration of methacholine causing a $>20 \%$ fall in $\mathrm{FEV}_{1}<8 \mathrm{mg} / \mathrm{ml}$ ). COPD was indicated by a post-bronchodilator $\mathrm{FEV}_{1} / \mathrm{VC}<70 \%$, and history of cigarette smoking or smoker's inclusions within macrophages.

$\mathrm{FEV}_{1}$ and $\mathrm{FEV}_{1} / \mathrm{VC}$ were measured according to ATS standards $10 \mathrm{~min}$ after subjects received $200 \mu \mathrm{g}$ of Salbutamol. Sputum was induced and processed according to previously published methods [7]. Saline-induced bronchoconstriction was defined as a $\geq 15 \%$ drop in $\mathrm{FEV}_{1}$ from pre-saline values at any of the concentrations of saline. Prior to induction, subjects did not withhold their regular medications, including long-acting bronchodilators, as per our protocol. Metachromatic cells were stained using toluidine blue in a subset of patients who also had their tryptase measured in cell-free sputum supernatant by ELISA. Methacholine provocation test results (by the tidal breathing method; [8]) were available for 56 subjects, where bronchodilating medications were withheld as per guidelines [9]. Two subsets of patients with SIB were re-evaluated 8-12 weeks after either reducing their dose of LABA by half $(n=36)$ or after treating them with Montelukast $10 \mathrm{mg}$ daily $(\mathrm{n}=20)$, as part of their routine clinical management. The study was approved by the Research Ethics Board of St. Joseph's Healthcare, Hamilton. Descriptive statistics were used to summarize the baseline characteristics of the patients. Multivariate logistic regression was used in forward and backward stepwise approach to determine predictors of SIB (PASW Statistics 18, SPSS, Chicago, IL).

\section{Results}

3565 patients had sputum induced for the assessment of bronchitis (Table 1), of whom $222(6.2 \%)$ had a $\geq 15 \%$ fall in $\mathrm{FEV}_{1}$. Overall, the predictors of Salbutamol failing to protect against SIB were the use of LABA (OR 2.02, 95\% CI 1.32-3.01, $\mathrm{p}=0.001$ ), high doses of ICS (OR 1.85, 95\% CI 1.11-3.09, $\mathrm{p}=0.02$ ), and baseline airflow obstruction $\left(\mathrm{FEV}_{1} / \mathrm{VC}<70 \%\right.$; OR 2.08, 95\% CI 1.40-3.10, $\left.\mathrm{p}<0.001\right)$ and $\mathrm{FEV}_{1}$ predicted $<60 \%$ (OR 3.29, 95\% CI 2.06-5.26, $\mathrm{p}<0.001)$. The presence or type of bronchitis were not predictors (Table 2). In the subset of patients who had a concurrent methacholine test $(\mathrm{n}=56)$, a $\mathrm{PC}_{20}$ methacholine of $<2 \mathrm{mg} / \mathrm{ml}$ was significantly associated with SIB

Table 1 Baseline characteristics of patients

\begin{tabular}{|c|c|c|c|c|}
\hline & \multicolumn{4}{|c|}{ Patients, no. (\%) } \\
\hline & $\begin{array}{l}\text { All patients } \\
\mathrm{n}=3565\end{array}$ & $\begin{array}{l}\text { Asthma } \\
n=2013\end{array}$ & $\begin{array}{l}\text { Possible asthma } \\
n=157\end{array}$ & $\begin{array}{l}\text { Non-asthmatic COPD } \\
n=1395\end{array}$ \\
\hline $\mathrm{FEV}_{1} \downarrow>15 \%(\%)$ & $222(6.2)$ & $152(7.5)$ & $22(14.0)$ & $48(3.4)$ \\
\hline Male sex $(n, \%)$ & $1569(44.0)$ & $708(40.3)$ & $100(63.7)$ & $761(54.5)$ \\
\hline Age year (mean, SD) & $54(17)$ & $47(17)$ & $44(13)$ & $66(11)$ \\
\hline ICS $(n, \%)$ & $1957(54.9)$ & $1661(82.5)$ & $102(65)$ & $194(13.9)$ \\
\hline $\operatorname{LABA}(n, \%)$ & $2426(68)$ & $1381(68.6)$ & $51(32.5)$ & $994(71.3)$ \\
\hline OCS $(n, \%)$ & $174(4.9)$ & $135(6.7)$ & $8(5.1)$ & $31(2.2)$ \\
\hline NB $(n, \%)$ & $328(16.6)$ & $106(5.3)$ & $15(9.6)$ & $207(14.8)$ \\
\hline EB $(n, \%)$ & $592(13.8)$ & $534(26.5)$ & $20(12.7)$ & $37(2.7)$ \\
\hline $\mathrm{FEV}_{1} \%$ (mean, SD) & $62.5(45.5)$ & $68.7(33.6)$ & $78.4(22.5)$ & $59.8(40.8)$ \\
\hline $\mathrm{FEV}_{1}$ NC \% (mean, SD) & $64.4(37.0)$ & $68.7(43.7)$ & $72.2(24.6)$ & $54.6(34.5)$ \\
\hline
\end{tabular}

ICS inhaled corticosteroid, NB neutrophilic bronchitis, $E B$ eosinophilic bronchitis, OCS oral corticosteroid, regular or intermittent, $L A B A$ long-acting $\beta$-agonist Eosinophilic bronchitis (EB) was defined as percentage of sputum eosinophils $\geq 3 \%$. Neutrophilic bronchitis (NB) was defined as a total cell count $\geq 15$ million cells/g of sputum and proportion of neutrophils $\geq 64 \%$ 
Table 2 Predictors of saline-induced bronchoconstriction

\begin{tabular}{|c|c|c|c|c|}
\hline & \multicolumn{4}{|c|}{ All patients, $n=3565$} \\
\hline & No. & $\begin{array}{l}\mathrm{FEV}_{1} \text { fall }>15 \% \text {, } \\
\text { no. }(\%)\end{array}$ & OR $(95 \% \mathrm{Cl})$ & $p$ value \\
\hline High ICS dose & 785 & $84(10.7)$ & $1.85(1.11-3.09)$ & 0.019 \\
\hline LABA use & 2426 & $142(10.0)$ & $2.02(1.32-3.10)$ & 0.001 \\
\hline $\begin{array}{l}\mathrm{FEV}_{1}<60 \% \text { pre- } \\
\text { dicted }\end{array}$ & 596 & $93(15.6)$ & $3.29(2.06-5.26)$ & $<0.001$ \\
\hline $\mathrm{FEV}_{1} / \mathrm{NC}<70 \%$ & 1165 & $149(12.8)$ & $2.08(1.40-3.10)$ & $<0.001$ \\
\hline
\end{tabular}

ICS inhaled corticosteroid, $\angle A B A$ long-acting $\beta$-agonist

(OR 7.50, 95\% CI 2.04-22.66, with $\mathrm{p}=0.002$ by Fisher's exact test).

Of the 36 asthmatics who had their dose of LABA halved, 25 (69\%) did not demonstrate SIB during a second sputum induction done 8-12 weeks after the dose adjustment. Sputum mast cell activity was measured in 20 subjects who demonstrated refractoriness to bronchodilation after saline induction (mean time for $\mathrm{FEV}_{1}$ to return to within $5 \%$ of pre-induction baseline was $38 \pm 6 \mathrm{~min})$, and this revealed that metachromatic cells $(2.2 \pm 0.8 \%$ vs. $0 \%)$ and tryptase $(5.6 \pm 1.8$ vs. $0.8 \pm 1.4 \mathrm{pg} /$ $\mathrm{ml}$ ) were both increased when compared to reference values [7]. In $14(70 \%)$ of these patients, the addition of Montelukast for 8-12 weeks resulted in reduced SIB and a faster recovery of $\mathrm{FEV}_{1}$ (mean time $17 \pm 8 \mathrm{~min}$ ).

\section{Discussion}

We confirmed previous observations that baseline airflow limitation and airway hyperresponsiveness to a direct stimulus such as methacholine can predict the loss of bronchoprotection to Salbutamol during saline induction [2], but also established that LABA use is a risk factor in a mixed population of obstructive airway diseases. LABA appears to cause these effects by way of receptor tolerance, [10-13]. $\beta$-receptor tolerance of airway smooth muscle cells can manifest as reduced bronchodilation, whereas for mast cells may manifest with an increased propensity to release inflammatory mediators [14]. For those on high-dose LABA, we found that reducing the dose by half led to the resolution of SIB in almost $70 \%$ of subjects. This suggests that it is important to recognize this phenomenon and to reduce the dose of LABA rather than increasing it in those patients with asthma who may have tolerance either to its bronchodilator or bronchoprotective effects.

Although we did not observe the cellular nature of bronchitis in our study to be a predictor of tolerance to SIB, there is evidence to suggest that the tolerance to bronchoprotection occurs more readily to indirect rather than to direct bronchconstrictive agents suggesting that airway inflammation may contribute to this phenomenon. One possible explanation that may account for these previous findings is airway mast cell activity that we do not routinely assess in quantitative sputum cell counts. This is supported by a study demonstrating that regular short-acting $\beta$-agonist leads to higher sputum levels of tryptase and metachromatic cells (mostly basophils), and an enhanced early and late asthmatic response [14]. Our findings corroborate a role for mast cells, as we showed less SIB and a more rapid recovery of FEV ${ }_{1}$ after SIB with the use of Montelukast in those with elevated sputum tryptase and metachromatic cells.

The major limitation of this study is the retrospective design of this study, which prevents the establishment of a causal relationship. LABA dose was not available for all patients and this study was not powered to detect differences between Formoterol and Salmeterol. Non-respiratory medications which may impact relevant pathways, including $\beta$-adrenergic blockers (e.g. eye drops, tablets) were not recorded within this retrospective survey. Finally, the interventions were not evaluated in a placebo, controlled, randomised trial design thus limiting interpretation of the efficacy that we observed.

\section{Conclusions}

In summary, we report two clinically relevant findings regarding airway pathophysiology that could be gleaned during the process of sputum induction using hypertonic saline: first, failure of Salbutamol to protect against saline-induced bronchoconstriction should raise suspicion of tolerance to the bronchoprotective effect of $\beta$-agonists. Such patients may benefit from reducing the dose or frequency of use of LABA. Second, a prolonged recovery time (refractoriness) of $\mathrm{FEV}_{1}$ following saline bronchoconstriction may indicate mast cell activity and may suggest that these are patients who may respond to mast-cell directed therapy or therapy directed against products of mast cells such as leukotriene receptor antagonists. It would be relevant to examine this phenomenon in relation to the mast cell signatures that have recently been reported using transcriptomic analysis of sputum $[15,16]$. It is important to test both LABA dose reduction to improve $\beta$-agonist sensitivity and mast-cell targeted therapy to improve refractoriness to hyperosmolar stimuli induced bronchoconstriction in placebo-controlled randomised clinical trials.

\section{Abbreviations}

SIB: saline-induced bronchoconstriction; AHR: airway hyperresponsiveness; LABA: long-acting $\beta$-agonist; ICS: inhaled corticosteroid; EB: eosinophilic bronchitis; NB: neutrophilic bronchitis. 


\section{Authors' contributions}

$\mathrm{PN}, \mathrm{JB}$ and HW designed the study and edited the manuscript. HW, MK and TH collected and analyzed the data, and wrote the manuscript. All authors read and approved the final manuscript.

\section{Author details}

${ }^{1}$ Firestone Institute for Respiratory Health, St. Joseph's Healthcare, 50 Charlton Avenue East, Hamilton, ON L8N 4A6, Canada. ${ }^{2}$ Department of Medicine, McMaster University, Hamilton, ON, Canada. ${ }^{3}$ John Hunter Hospital, Newcastle, NSW, Australia.

\section{Acknowledgements}

Not applicable.

\section{Competing interests}

PN holds membership on advisory boards for AstraZeneca, Teva, Roche, and Sanofi Aventis, and received honoraria from these companies as well as Novartis and Boehringer Ingelheim for lectures given at symposia. He has also consulted with Knopp, Theravance, 4D Therapeutics, and Inflamax. The other authors declare no competing interests or conflicts of interest.

\section{Availability of data and materials}

The datasets used and/or analysed during the current study are available from the corresponding author on reasonable request.

\section{Consent for publication}

Not applicable.

\section{Ethics approval and consent to participate}

This study was approved by the Research Ethics Board of St. Joseph's Healthcare, Hamilton. This ethics board approved the collection and maintenance of a sputum cell count database for research.

\section{Funding}

This research did not receive any specific grant from funding agencies in the public, commercial, or not-for-profit sectors. PN is supported by the Frederick E. Hargreave Teva Innovation Chair in Airway Diseases. This had no impact on the study design, data collection and analysis, or contents of the manuscript.

\section{Publisher's Note}

Springer Nature remains neutral with regard to jurisdictional claims in published maps and institutional affiliations.

Received: 19 February 2018 Accepted: 16 April 2018

Published online: 10 May 2018

\section{References}

1. Vlachos-Mayer H, Leigh R, Sharon RF, Hussack P, Hargreave FE. Success and safety of sputum induction in the clinical setting. Eur Respir J. 2000;16(5):997-1000
2. ten Brinke A, de Lange C, Zwinderman AH, Rabe KF, Sterk PJ, Bel EH. Sputum induction in severe asthma by a standardized protocol. Am J Respir Crit Care Med. 2001;164(5):749-53.

3. Barnes PJ. Beta-adrenergic receptors and their regulation. Am J Respir Crit Care Med. 1995;152(3):838-60.

4. Haney S, Hancox RJ. Tolerance to bronchodilation during treatment with long-acting beta-agonists, a randomised controlled trial. Respir Res. 2005;6(1):1-7

5. Jabbal S, Manoharan A, Lipworth BJ. Bronchoprotective tolerance with indacaterol is not modified by concomitant tiotropium in persistent asthma. Clin Exp Allergy. 2017:163:44-7.

6. Zuhlke IE, Kanniess F, Richter K, Nielsen-Gode D, Bohme S, Jorres RA, et al. Montelukast attenuates the airway response to hypertonic saline in moderate-to-severe COPD. Eur Respir J. 2003;22(6):926-30.

7. Pizzichini E, Pizzichini MMM, Efthimiadis AE, Evans S, Morris MM, Squillace $D$, et al. Indices of airway inflammation in induced sputum: reproducibility and validity of cell and fluid-phase measurements. Am J Respir Crit Care Med. 1996:154:308-17.

8. Cockcroft DW, Berscheid BA. Standardization of inhalation provocation tests. Chest. 1982;82(5):572-5.

9. Coates AL, Wanger J, Cockcroft DW, Culver BH, the Bronchoprovocation Testing Task Force, Carlsen KH, Diamant Z, et al. ERS technical standard on bronchial challenge testing: general considerations and performance of methacholine challenge tests. Eur Respir J. 2017:49(5):1601526.

10. Jones SL, Cowan JO, Flannery EM, Hancox RJ, Herbison GP, Taylor DR. Reversing acute bronchoconstriction in asthma: the effect of bronchodilator tolerance after treatment with formoterol. Eur Respir J. 2001;17(3):368-73.

11. Hancox RJ, Aldridge RE, Cowan JO, Flannery EM, Herbison GP, McLachlan $\mathrm{CR}$, et al. Tolerance to beta-agonists during acute bronchoconstriction. Eur Respir J. 1999;14(2):283-7.

12. Haney S, Hancox RJ. Rapid onset of tolerance to beta-agonist bronchodilation. Respir Med. 2005:99(5):566-71.

13. Lipworth BJ, Aziz I. A high dose of albuterol does not overcome bronchoprotective subsensitivity in asthmatic subjects receiving regular salmeterol or formoterol. J Allergy Clin Immunol. 1999;103(1):88-92.

14. Swystun VA, Gordon JR, Davis EB, Zhang X, Cockcroft DW. Mast cell tryptase release and asthmatic responses to allergen increase with regular use of salbutamol. J Allergy Clin Immunol. 2000;106(1):57-64.

15. Hekking P-P, Loza MJ, Pavlidis S, de Meulder B, Lefaudeux D, Baribaud $F$, et al. Pathway discovery using transcriptomic profiles in adult-onset severe asthma. J Allergy Clin Immunol. 2017;141(4):1280-90.

16. Berthon BS, Gibson PG, Wood LG, MacDonald-Wicks LK, Baines KJ. A sputum gene expression signature predicts oral corticosteroid response in asthma. Eur Respir J. 2017;49(6):1700180.

\footnotetext{
Ready to submit your research? Choose BMC and benefit from:

- fast, convenient online submission

- thorough peer review by experienced researchers in your field

- rapid publication on acceptance

- support for research data, including large and complex data types

- gold Open Access which fosters wider collaboration and increased citations

- maximum visibility for your research: over 100M website views per year
}

At BMC, research is always in progress.

Learn more biomedcentral.com/submissions 